\title{
Perspectives Perspectives
}

\begin{abstract}
This section features: (1) reactions of readers to articles and reviews published in the Journal and the replies of authors to whom the comments are addressed (if forthcoming) and (2) viewpoints and opinions expressed in the form of a report, commentary, or interview on issues or topics of current interest.
\end{abstract}

Cette section sera consacrée à deux types d'articles:

1. La réaction des lecteurs aux articles parus dans la revue et la réponse de leurs auteurs, s'il y a lieu.

2. Les points de vue et les opinions, présentés sous forme de comptes rendus, de commentaires, de chroniques ou d'entrevues, sur des sujets d'actualité ou d'intérêt général.

\section{ESL TEACHER EDUCATION: FIVE PRINCIPLES}

\section{Maureen Hynes}

The past ten years have seen a considerable shift in second language teaching theory towards what is known as a "communicative approach." However, the term "communicative language teaching" (CLT) is still imprecise, and researchers, curriculum designers, teachers and teacher educators are still striving to articulate fully the features of this approach. Furthermore, the development of CLT has not, by and large, taken place with systematic reference to the field of curriculum. Exceptions to this observation include the concern by some British educators to draw up curriculum "axioms" from which to design a communicative syllabus (Candlin 1983 represents one contribution to this discussion). Finally, although the acceptance of CLT has involved some recognition that the move towards "learner-centredness" is part of a larger educational development in many western countries (Brumfit, 1980; Littlewood, 1984; Young and Lee, 1985), there have been few attempts in the field of second language teaching to tap broader curriculum discussions.

A consequence of the sort of imprecision about the nature of CLT noted above is that the attention to developing curricula for second language learners has far exceeded the development of curricula for second language teacher education, whether preservice or inservice. In 
this paper, I will attempt to forge a link between the fields of curriculum and second language teaching by proposing and exploring several principles for teacher education, especially for teachers of adult ESL learners. The applicability of these principles will be discussed in relation to both preservice and inservice training programs.

The needs of preservice and inservice teachers differ, with regard to subject-matter expertise and with regard to familiarity with the learners and the social milieu. Nevertheless, both preservice and inservice teachers may find themselves in the midst of a role change. As a result of curriculum innovation in second language teaching, an innovation that is often imposed rather than chosen, experienced teachers encounter new expectations about their roles-e.g., as "facilitators" rather than transmitters of information about the formal properties (phonology, morphology, lexicon and syntax) of the language. In CLT, teachers confront objectives that they may find controversial. For example,

The primary objectives for a communication-oriented second language programme must be to provide the learners with the information, practice and much of the experience needed to meet their communicative needs in the second language. (Canale and Swain, 1980:28)

Teachers may also find it hard to accept the view of language learning underlying this objective: that learners develop syntactic structures from communicative experience, rather than first learning these structures and then using them in interaction (Hatch, 1978).

Further, often without sharing or understanding these views about the nature of language learning, experienced teachers are expected to fulfill the "active implementor" curriculum function, and occasionally, the "partner in development" function (see Connelly and Ben-Peretz 1980). Thus, the five principles proposed here for teacher education programmes build toward a research and curriculum development model of teacher training, in which both the "habit of reflection" on curricular problems and the "practical know-how" for developing and presenting language learning experiences, are accepted as proper goals (Feiman 1979).

\section{A teacher education curriculum should foster inquiry and problem- solving.}

First of all, an approach that fosters problem-solving is strongly suggested by the nature of the subject-matter itself-language, which, in ESL classes, is both the object and the medium of instruction. Candlin (1983) argues that language learning and teaching is a social enterprise in which form, intention, value and context interplay while learners exercise the primary language abilities of interpretation, expression and negotiation 
(of meaning and social relationships). Language, then, is a tool for human problem-solving, and classroom activities should therefore provide language experiences to this end. The object of inquiry, towards which all curriculum participants work, is a clearer understanding of language learning and the activities and strategies that promote this learning.

This principle is based on acceptance of Katz's (1977) concept of congruence, as described by Ben-Peretz:

the way teachers are taught should be congruent, in many basic aspects, with the way they are supposed to teach (1984:13)

For inservice teachers, an acceptance of this principle may provide the need-based motivation that Haysom and Sutton (1975) suggest must balance the curricular tendency to stress objectives. An interesting example of a research and curriculum development problem that inservice teachers might fruitfully investigate in an ESL setting is one that Buchmann (1984) raises, and that ESL teachers themselves frequently raise about CLT: how can we evaluate problem-solving language tasks in order to determine whether and how they promote learning? Further, through a classroom emphasis on problem-solving tasks which focus the learner's attention on the "non-linguistic outcomes of the task rather than on the accompanying and facilitating language" (Candlin, 1983), are we in danger of developing what Buchmann describes as "a sense of success and accomplishment that may be deceptive"?

\section{A teacher education curriculum should be supportive.}

Again, the concept of congruence underlies this principle. ESL teachers, long before the advent of a communicative approach, generally accepted the notion that language learning environments must be supportive in nature. Teachers recognized that learners often experience basic classroom activities, e.g., simply answering a question, as a risk-taking situation in which they both judge themselves and are judged (Stevick, 1976).

For inservice teachers, the supportiveness is particularly important if a research and curriculum development model is accepted for the programme in the overall context of curriculum innovation. Stenhouse cites MacDonald (1973) that "Genuine innovation begets incompetence. It deskills teacher and pupil alike, suppressing acquired competences and the development of new ones" (1975:171). In arguing for a research model of curriculum, going beyond an objectives-driven one or a process model, Stenhouse further comments that

... the close examination of one's professional performance is personally threatening; and the social climate in which teachers work 
generally offers little support to those who might be disposed to face that threat. (1975:159)

Through the study of questions and the attempts to resolve problems of interest to them, and through a supportive training environment with varied forms of feedback and-not neglecting essentials-the provision of adequate resources in terms of time and facilities, the "personally threatening" aspects of research and curriculum development activities can, to some extent, be minimized for both preservice and inservice ESL teachers.

3. A teacher education curriculum should be collaborative and participatory.

This third principle is again supported by an acceptance of the concept of congruence and by an understanding of the social role of language and language learning. If the inquiry model has as its object the further understanding of the nature of language learning, this object is best served by allowing all the participants in curriculum development to be, in a sense, learners. Furthermore, difficult as it is to attain, the ongoing participation of all members of the curriculum implementation or innovation project often contributes to a stronger commitment to the programme. Cumming's (1984) model for inservice ESL teacher training goes a considerable way to demonstrate how this degree of participation may be achieved. If, for example, all the participants-curriculum designers, administrators, sponsors, teachers and learners contribute in some way, not only to programme evaluation, but also to the design of evaluation instruments, the needs of the programme are served in several ways at once: learners can use this opportunity to design an evaluation instrument as a language learning experience; and teachers and administrators can take this project on as a research and curriculum development investigation.

In considering this principle, it is important to allow for the interplay of the "supportiveness" principle. In this case, participation and collaboration skills cannot be assumed to pre-exist the curriculum development phase or teacher preservice training programme: again, adequate resources in terms of training and feedback on group process and task maintenance must be structured into the project.

4. A teacher education curriculum should be integrative.

Particularly in preservice ESL teacher education courses, a very fragmented view of language learning and teaching emerges, and the student teacher is left to synthesize these on his or her own. This state of affairs, it seems, is partly a result of the attempt to "graft on" to earlier education curricula newer views of language learning: consequently, these courses 
offer sections on "the language lab," separately from sections on speaking, pronunciation and listening. In addition, many of these courses provide a different specialist in each area for each section, and there is a somewhat misleading division between theory and practice evident in this sort of time-tabling. The lack of thorough attention to developing teacher education principles for second languages has led to the ignoring of questions like, "Is the language lab an appropriate facility or technique for teachers to use within a communicative approach?"

In the case of inservice teacher education, a frequent situation in public institutions offering ESL to adult learners is that there is no overall coherent inservice training policy; consequently, workshops and seminars, when offered, are responses to crises within the department, for example, over a communicative test that has proven unpopular with teachers because it focusses, not on language accuracy, but on overall fluency.

One possible solution for the lack of integration in both preservice and inservice education is the imposition of Schwab's (1978) model of the four commonplaces of education - the learner, the teacher, the subject matter and the social milieu - as an integrating tool in conceptualizing teacher education curricula. For an interesting parallel to Schwab's model, but in particular reference to second language teaching, see Stern (1983). Stern identifies five aspects of a framework for the examination of second language learning: social context, learner characteristics, learning conditions, learning processes and learning outcomes (see the Appendix). The development, in any case, of an overarching paradigm to minimize fragmentation of the skills and content is generally needed in ESL teacher education. This question relates to one raised earlier, about the teaching of "a repertoire of techniques without developing the capacity to put the techniques to genuinely educative use" (Feiman 1979:77).

\section{A teacher education curriculum should be critical.}

A virtually uncharted area in mainstream ESL teaching to adults and in ESL teacher education is the question of the hidden curriculum (Martin, 1976), and its role in transmitting and maintaining through language instruction, beliefs and values about the society which provides this instruction. With the exception of writers like Candlin (1984), Hartman and Judd (1978), Judd (1984), Porreca (1984) and Wallerstein (1983), very few attempts have been made to acknowledge and expose the nature of this hidden curriculum for ESL. Furthermore, these observations have not been posed in terms of the hidden curriculum nor have they been synthesized. Therefore, they have rarely been available for discussion in teacher education programmes. 
Candlin (1984) warns that the creation of harmonious interaction, for example, in the ESL classroom may serve to anaesthetize problem-coping capacities or to discourage problem-sensing. These kinds of observations must be reconciled with the principles of supportiveness and participation discussed earlier in this paper. In addition we must examine the notion of the social climate that ESL teachers strive to establish in their classes. The exclusion of 'controversial' topics is well worth exploring, especially when the intended learners are adults.

One aspect of the hidden curriculum, the visibility and characterization of women in ESL texts, has been subjected to very little critique, as is suggested by Porreca's (1984) follow-up study of Hartman and Judd's (1978) investigation of sexism in ESL materials. The sensitivity of second language teachers to the way in which language, and language learning materials and tasks, maintain and reinforce sexist values, moreover, could be extended through studies of the same type focusing on the dominance of middle-class values in ESL texts. Judd (1984) raises for ESL and EFL teachers such issues as the role that English instruction can play in non-English speaking countries, for example the eventual suppression of the native language. Wallerstein (1983) re-interprets Freire's concepts for the teaching of literacy to the teaching of English in a North American setting, and points out how few of the materials available to teachers direct us to begin with the learner's experiences and to move towards a social rectification of the problems our learners encounter.

The operation of the hidden curriculum is obviously a question that could be undertaken in research projects in inservice and preservice teacher education curricula, and the sharing of these reports would benefit the entire field of second language teaching by giving us a forum in which to acknowledge and explore these covert means of encoding and preserving social knowledge.

In suggesting these five principles for preservice and inservice ESL teacher education, the concern throughout has been to provide curriculum guidelines which would prepare teachers to see themselves as active participants in educational problem-solving rather than simply recipients of solutions that others have devised.

\section{REFERENCES}

Ben-Peretz, M. (1975). The concept of curriculum potential. Curriculum Theory Network, 5(2), 52-62.

Ben-Peretz, M. (1984). Curriculum theory and practice in teacher-education programmes. In L. Katz and J. Raths (Eds.), Advances in teacher education. Vol. I. Norwood, N.J.: Ablex Publishing. 
Brumfit, C.J. (1980). Ideology, communication and learning to use English. English Language Teaching Journal, 34(3), 169-172.

Buchmann, M. (1984). The priority of knowledge and understanding in teaching. In L. Katz and J. Raths (Eds.), Advances in teacher education. Vol. I. Norwood, N.J.: Ablex Publishing.

Canale, M. \& Swain, M. (1980). Theoretical bases of communicative approaches to second language teaching and testing. Applied Linguistics, $1(1), 1-47$.

Candlin, C.N. (1983, March). Syllabus design as a critical process. Paper presented at the Colloquium on Syllabus/Curriculum Design, 17th Annual TESOL Convention, Toronto.

Candlin, C.N. (1984, March). The ideological basis of a communicative curriculum. Paper presented at the Colloquium on the Politics of Teaching ESL, 18th Annual TESOL Convention, Houston.

Connelly, F.M. \& Ben-Peretz, M. (1980). Teachers' role in using and doing of curriculum development. Journal of Curriculum Studies, 12(21), 95-107.

Cumming, A. (1984). Compiling instructors' perceptions of learners' deficiencies: a problem-centred approach to inservice training and language programme development. TESL Manitoba Journal, 1 (1), 38-45.

Feiman, S. (1979). Technique and inquiry in teacher education: a curriculum case study. Curriculum Inquiry, 9(1), 63-79.

Hartman, P.L. \& Judd, E.L. (1978). Sexism and TESOL materials. TESOL Quarterly, 12(4), 383-393.

Hatch, E. \& Long, M. (1980). Discourse analysis, what's that? In D. LarsenFreeman (Ed.), Discourse analysis and second language research. Rowley, Mass.: Newbury House.

Hayson, J.T. \& Sutton, C.R. (1975). Motivation: a neglected component in models for curriculum improvement. Curriculum Theory Network, 4(1), 23-34.

Judd, E.L. (1983). TESOL as a political act: a moral question. In J. Handscombe, R.A. Orem and B.P. Taylor (Eds.), On TESOL '83, Georgetown: TESOL.

Littlewood, W. (1984). Foreign and second language learning: language acquisition research and its implications for the classroom. Cambridge: Cambridge University Press.

Martin, J. (1976). What shall we do with a hidden curriculum when we find one? Curriculum Inquiry, 6(2), 135-151.

Porreca, K.L. (1984). Sexism in current ESL textbooks. TESOL Quarterly, 18(4), 705-724.

Schwab, J.J. (1973). The practical: Translation into curriculum. School Review, $81,501-511$.

Stenhouse, L. (1975). An introduction to curriculum research and development. London: Heinemann Educational Press.

Stern, H.H. (1983). Fundamental concepts of language teaching. Oxford: Oxford University Press.

Stevick, E.W. (1976). Teaching English as an alien language. In R. Crymes and J. Fanselow (Eds.), On TESOL '76. Georgetown: TESOL. 
Wallerstein, N. (1983). The teaching approach of Paolo Freire. In J. Oller Jr. and P.A. Richard-Amato (Eds.), Methods that work. Rowley, Mass.: Newbury House.

Young, R. and Lee, S. (1984). EFL curriculum innovation and teachers' attitudes. In P. Larson, E.L. Judd and D. Messerschmidt (Eds.), On TESOL'84. Georgetown: TESOL.

\section{THE AUTHOR}

Maureen Hynes teaches ESL and trains teachers at George Brown College and at the Faculty of Education at the University of Toronto. Her experiences as a teacher trainer at Sichuan University form the basis of her book, Letters from China, Toronto: Women's Press, 1981. 


\section{APPENDIX}

Framework for examination of second language learning

2. Learner characteristics

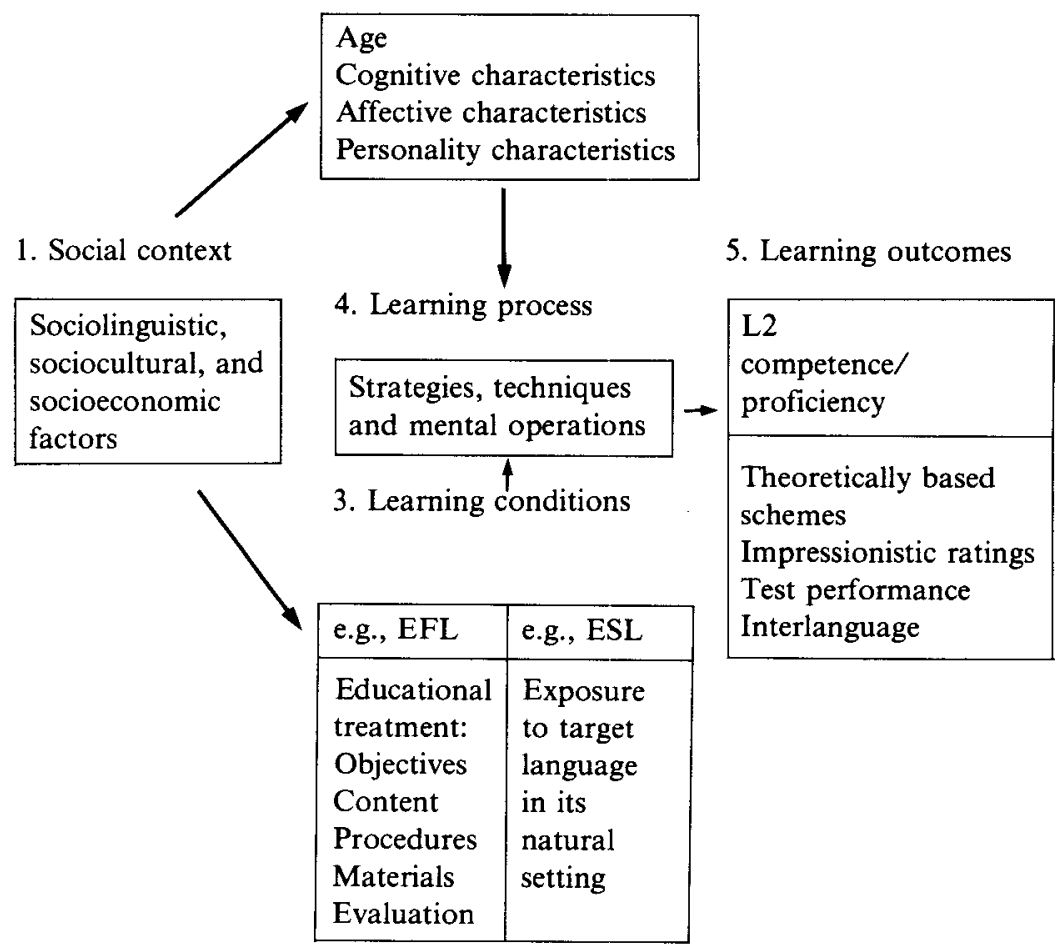

From: H.H. Stern. 1983. Fundamental concepts of language teaching. Oxford: Oxford University Press. (Figure 16.1) 
